\title{
A preliminary study of fecundity of whiting, Merlangius merlangus euxinus (Linnaeus, 1758) in coast of Tirebolu (Eastern Black Sea)
}

\author{
Burcu Taylan ${ }^{1 *}$, Sule Gurkan ${ }^{1}$, Ertan Taskavak ${ }^{1}$, Arzu Aydın Uncumusaoglu² \\ ${ }^{1}$ Department of Hydrobiology, Faculty of Fisheries, Ege University, 35100 Izmir, Turkey \\ ${ }^{2}$ Environmental Engineering, Giresun University, 28200 Giresun, Turkey
}

\section{A R T I C LE IN F O}

\section{Research Article}

Received 16 November 2017 Accepted 11 December 2017

Keywords:

Whiting

Merlangius merlangus euxinus

Fecundity

Eastern Black Sea

Turkey

*Corresponding Author:

E-mail: burcu.taylan@ege.edu.tr

\section{A B S T R A C T}

In this research, a preliminary study was carried out in January and February 2014 to determine the fecundity of the whiting species in Tirebolu, Eastern Black Sea. After the total length $(\mathrm{cm})$ and weight $(0.01 \mathrm{~g})$ of the 70 fish specimens were measured in the laboratory, they were dissected for sex determination. Using the 20 ovaries at the third and fourth maturation stages, 3 sub-samples which is $2-5 \%$ of the total ovary weight (from the anterior, median and posterior parts of the ovary) were taken from each ovary to determine the fecundity, and hydrated oocytes were counted with gravimetric method. Total fecundity, total oocytes number in the ovary were computed with the formula $\mathrm{F}=(\mathrm{n} \times \mathrm{G}) / \mathrm{g}$. The total length-weight values were $12.6-23.3 \mathrm{~cm}$ (mean 17.08 \pm 2.12$)$ and 15.59-95.72 g (mean $41.07 \pm 16.75$ ), respectively, and total length-weight relationship was computed as $\mathrm{W}=0.0073 \mathrm{~L}^{3.024}\left(\mathrm{R}^{2}=0.94\right)$ for the 70 fishes evaluated. Fecundity was computed as 3.247-30.534 (mean: 10.139 \pm 6.953 ) eggs and a linear relationship between fecundity and total length was calculated as $F=0.0186 \mathrm{~L}^{4.5631}\left(\mathrm{R}^{2}=0.70\right)$. In conclusion, the fecundity results of this prelaminar study were compared with similar studies on the whiting species from Black Sea and other seas.

DOI: https://doi.org/10.24925/turjaf.v6i3.322-325.1700

\section{Introduction}

Whiting, Merlangius merlangus (L., 1758) is a cold water species and the adults prefer water temperatures between 5 and $16^{\circ} \mathrm{C}$. Whiting inhabits inshore waters over muddy grounds and forms shoals at depths between 30 $100 \mathrm{~m}$, but generally does not live deeper than $85 \mathrm{~m}$ (Whitehead et al., 1986). The species is known as batch Spawners (literature knowledge), i.e., only a portion of the Yolked (literature knowledge) oocyte is spawn in each batch, and spawning continues throughout the year (Murua and Saborido-Rey, 2003). The whiting, which is native to the Northeast Atlantic in which the Mediterranean and the Black Sea are located, is assessed in the LC (Least Concern) category by IUCN. Although the total biomass estimates and stock assessments of Merlangius merlangus in the world have not stable structure and fluctuates from place to place, in the Black Sea they have referred to an increase in recent years (Nedreaas et al., 2014).

Although there are various studies about the biological properties of the species on a universal basis and in Turkey (Volodin, 1996; Bradova and Prodanov, 2003; Maximov et al., 2007; Milić and Kraljević, 2011; Şahin and Akbulut, 1997; Samsun and Erkoyuncu, 1998; Çiloğlu et al., 2001; Göksungur and Erdem, 2005; Atasoy et al. 2006; Bilgin et al., 2012; Sağlam and Sağlam, 2012; Mazlum and Bilgin, 2014), studies on fecundity are a very few. In the various studies, the whiting's fecundity was determined by Kandler (1958) for Baltic Sea, Merstorff (1959) for the Southern North Sea, Hislop and Hall (1974) for North Sea, Minch and Iceland, Hislop (1975) for North Sea and Ismen (1995) for the Black Sea coasts of Turkey.

Whiting is an important species in Turkey, particularly in the Black Sea fisheries and according to the TUIK (Turkish Statistical Institute) data of the year 2016, the total fishing is 11540.8 tons. For this reason, the continuity of the species' population is extremely important. Information such as breeding time and duration, first breeding length, fecundity and sex ratio of a fish species is vitally important in having more information about the stock status (Murua et al., 2003). Studies on fecundity of fish species are pertinent and useful for systematics in racial studies related to total population estimation and productivity (Adebiyi, 2013).

In this preliminary study; some information about the breeding biology has been tried to be obtained by determining spawning efficiency and egg diameter values in January and February for whiting which is an 
economically important species in the Black Sea fisheries. In the future, with the whole year sampling it may be aimed to carry out more detailed studies such as determination of spawning season depending on gonad development and microscopic evaluation of gonads by histological studies, and as a result to reveal the precise reproduction parameters of the species.

\section{Material and Method}

In this study, a total of 70 whiting samples were obtained from commercial fishing boats fishing in Tirebolu in January and February of 2014. The total length $(\mathrm{cm})$ and weight $(0.01 \mathrm{~g})$ of the fish specimens were measured in the laboratory, and then they were dissected for sex determination. The total length-weight relationship of the samples was evaluated according to Ricker (1975). In the evaluation of length-weight relation, the equation $\mathrm{W}=\mathrm{a} \times \mathrm{L}^{\mathrm{b}}$ was used. In this equation $\mathrm{W}$ is total weight; L, total length; $a$, inclination and $b$, regression coefficient.

The gonadal developmental stages in females were determined macroscopically according to a five-point maturity scale for partial spawners (Table 1) described by Holden and Raitt (1974). The ovaries to be used in determining the fecundity were fixed in $4 \%$ formalin solution. Subsequently, using the 20 ovaries at the third and fourth maturation stages 3 sub-samples which is $2-5 \%$ of the total ovary weight (from the anterior, median and posterior parts of the ovary) were taken from each ovary for the fecundity determination, and hydrated oocytes were counted with gravimetric method. Total fecundity, total oocytes number in the ovary were computed with the formula $F=(n \times G) / g$ (Valladolid and Przybylski 2008).

\section{Results}

The total length-weight values of the evaluated 70 fishes were 12.6-23.3 cm (mean 17.08 \pm 2.12 ) and 15.59$95.72 \mathrm{~g}$ (mean $41.07 \pm 16.75$ ), respectively. Total lengthweight relationship was computed as $\mathrm{W}=0.0073 \mathrm{~L}^{3.024}$ $\left(\mathrm{R}^{2}=0.94\right)$ (Fig. 1).

In our study, fecundity was computed as 3.247-30.534 (mean: 10.139 \pm 6.953 ) eggs. A linear relationship between fecundity and total length was calculated as
$\mathrm{F}=0.0186 \mathrm{~L}^{4.5631}\left(\mathrm{R}^{2}=0.70\right)$ (Fig. 2). Diameter of hydrated oocytes was found as $0.98-1.30 \mathrm{~mm}$ (mean: $1.10 \pm 0.11$ ).

\section{Discussion}

In this study which fecundity of the whiting samples obtained in the winter of 2014 was examined, the calculated mean length values indicate that the Tirebolu fishermen obey the fishing prohibitions applied during the January to February months in the region because of catchable length values of fish (Anonim 2016). A total of 70 specimens were examined and the relationship between length and weight was detected as $\mathrm{W}=$ $0.0073 \mathrm{~L}^{3.024}\left(\mathrm{R}^{2}=0.94\right)$. The length-weight relation of the whiting population was given as $0.0064 \mathrm{~L}^{3.0441}\left(\mathrm{R}^{2}=0.88\right)$ by Sağlam and Sağlam (2012) for the Southeastern Black Sea, while Çiloğlu et. al. (2001) $\left(\mathrm{R}^{2}=0.986\right)$ computed those equations as $\mathrm{W}=0.0037 \mathrm{~L}^{3.2594} \quad\left(\mathrm{R}^{2}=0.986\right)$ and $\mathrm{W}=0.0042 \mathrm{~L}^{3.2069} \quad\left(\mathrm{R}^{2}=0.980\right)$ in female and male individuals, respectively, in the study conducted at the coasts of Trabzon-Yomra (Eastern Black Sea). Therefore, it is assumed that the values we obtained from the whiting samples in this study are parallel with to the findings of these researchers, and consequently they show an isometric growth during the winter period in Tirebolu.

Fecundity was determined between 3.247 and 30.534 (mean: $10.139 \pm 6.953$ ) according to 20 ovaria examined in our study. In order to determine the fecundity, Atasoy et al. (2006) studied the individuals at the lengths between 11 and 17 centimeters in the Sea of Marmara and as a result they found the value as $14582 \pm 1220$ eggs. Uysal (1990) and İşmen (1995) stated that the whiting fecundity is an average of 12000 eggs and 263000 eggs, respectively, for the eastern Black Sea. These differences emerged in the fecundity values are thought to be due to differences in fish lengths, growth rates and nutrition in different areas (Hislop and Hall, 1974).

While the egg diameters of hydrated oocytes are found to be $0.98-1.30 \mathrm{~mm}$ (mean: $1.10 \pm 0.11$ ) in our study, those values were reported as $1.22 \pm 0.01 \mathrm{~mm}, 1.10-1.33 \mathrm{~mm}$ and 0.97-1.32 mm by Atasoy et al. (2006), Dehnik (1973) and İşmen (1995), respectively and it is thought that the values in our study are in agreement with the values of other researchers.

Table 1 A five-point maturity scale for partial spawners*

\begin{tabular}{|c|c|c|}
\hline Stage & State & Description \\
\hline I & Immature & $\begin{array}{l}\text { Ovary and testis about } 1 / 3 \text { rd length of body cavity. Ovaries pinkish, translucent; } \\
\text { testis whitish. Ova not visible to naked eye. }\end{array}$ \\
\hline II & $\begin{array}{l}\text { Maturing virgin and } \\
\text { recovering spent }\end{array}$ & $\begin{array}{l}\text { Ovary and testis about } 1 / 2 \text { length of body cavity. Ovary pinkish, translucent; testis } \\
\text { whitish, more or less symmetrical. Ova not visible to naked eye. }\end{array}$ \\
\hline III & Ripening & $\begin{array}{l}\text { Ovary and testis is about } 2 / 3 \text { rds length of body cavity. Ovary pinkish-yellow } \\
\text { colour with granular appearance, testis whitish to creamy. No trans- parent or } \\
\text { translucent ova visible. }\end{array}$ \\
\hline IV & Ripe & $\begin{array}{l}\text { Ovary and testis from } 2 / 3 \text { rds to full length of body cavity. Ovary orange-pink in } \\
\text { colour with conspicuous superficial blood vessels. Large transparent, ripe ova } \\
\text { visible. Testis whitish- creamy, soft. }\end{array}$ \\
\hline V & Spent & $\begin{array}{l}\text { Ovary and testis shrunken to about } 1 / 2 \text { length of body cavity. Walls loose. Ovary } \\
\text { may contain remnants of disintegrating opaque and ripe ova, darkened or } \\
\text { translucent. Testis bloodshot and flabby. }\end{array}$ \\
\hline
\end{tabular}

Holden and Raitt (1974) 


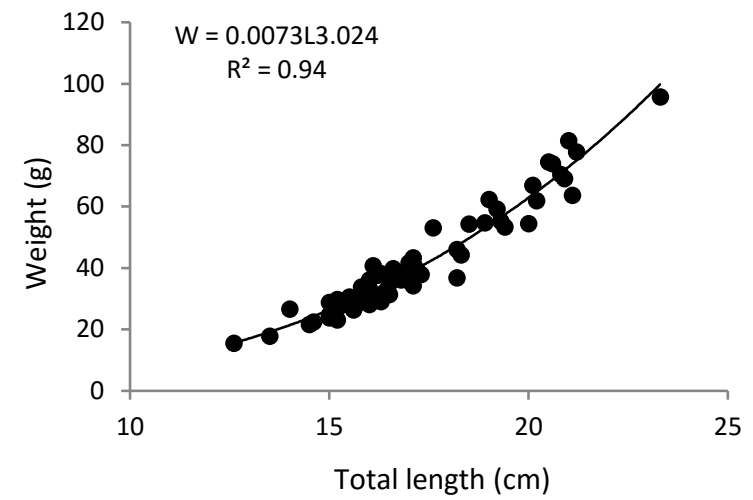

Figure 1 Total length-weight relationship of Merlangius merlangus euxinus

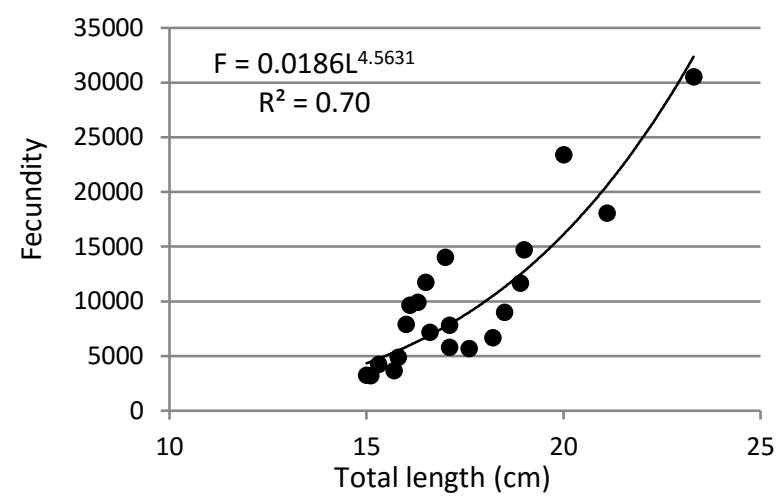

Figure 2 Fecundity-total length relationship of Merlangius merlangus euxinus

Kandler (1958) who studied the 37 whiting at the lengths between $25-39 \mathrm{~cm}$ before the spawning period in the Baltic Sea, determined fecundity as 108.000-221.000 eggs and computed the fecundity-size relationship as Fecundity $=72.000+2.404 \mathrm{~L}^{3}$, while Merstorff (1959) found the fecundity as 120400 - 151000 eggs among 37 whiting at the lengths of $23.5-38.5 \mathrm{~cm}$ in the south of the North Sea and the fecundity-length relationship as Fecundity $=0.0065 \times \mathrm{L}^{5.28}$. On the other hand, Hislop (1975) found out the fecundity as 170.000-2.089.000 eggs for the $25-51 \mathrm{~cm}$ whiting samples in the North Sea. According to the study conducted by İssmen (1995) on the Black Sea coast of Turkey between 1990-1993, the fecundity-length relationships were found to be $\mathrm{F}=\mathrm{aL}^{2.19}$ $(\mathrm{r}=0.75)$ for the west region and $\mathrm{F}=\mathrm{aL}^{2.20} \quad(\mathrm{r}=0.75)$, $\mathrm{F}=\mathrm{aL}^{3.36}(\mathrm{r}=0.85)$ and $\mathrm{F}=\mathrm{aL}^{2.74}(\mathrm{r}=0.80)$, respectively, for the east region in three-year period. Fecundity or reproductive success is known to vary from year to year (Nikolsky, 1969). The reason for this change may be fish size, as well as alterations in environmental conditions such as food, temperature and stress. (Treasurer, 1981; Tsai and Gibson, 1971; Bagenal, 1978). The fecunditylength relation value computed in our study is quite higher than that given by İşmen (1995). The fecunditylength relation value computed in our study is quite higher than that given by İşmen (1995). Therefore, we can consider that the species has changed its reproductive performance in over 20 years based on the current conditions of the region. However, the effects of the length values of the species caught in our study may also be relevant to this result. Similarly, it has also been suggested by Bowering (1980) that high fecundity levels are associated with maturation in the low lengths.

This study in which some reproductive characteristics of $M$. merlangus euxinus, an economically important species in our country, are determined for the winter period is a preliminary research. With sampling to be made during the overall year in the future, reproductive biology of the species may be established in detail with the determination of other breeding parameters such as spawning season, first maturity size as well as microscopic gonad development and ovulation frequency with histological studies. These results are considered to be beneficial in terms of the species' stock management.

\section{References}

Adebiyi FA. 2013. The sex ratio, gonadosomatic index, stages of gonadal development and fecundity of sompat grunt, Pomadasys jubelini (Cuvier, 1830). Pak J Zool., 45(1): 41-6.

Anonim. 2016. 4/1 numaralı ticari amaçlı su ürünleri avcılığının düzenlenmesi hakkında tebliğ (tebliğ no: 2016/35). Resmi Gazete 13.08.2016 Sayı: 29800.

Atasoy, E, Erdem, Ü, Cebeci, M, Yerli, B. 2006. Some biological characteristics of the whiting (Merlangius merlangus euxinus Nordmann, 1840) in the Marmara Sea, E.U. Journal of Fisheries \& Aquatic Sciences 2006, 23 (1/1): 33-37.

Bagenal, TB. 1978. Aspects of fish fecundity. Pages 75-101 in S. D. Gerking, editor. Ecology of freshwater fish production. Halsted Press, New York.

Bilgin S, Taşçi B, Bal H. 2012. Sexual seasonal growth of the European anchovy (Engraulis encrasicolus) caught by midwater trawl and purse seine in the southern Black Sea. Journal of the Marine Biological Association of the United Kingdom, Available on CJO 2012 doi:10.1017/S0025315412000732.

Bowering WR. 1980. Fecundity of Greenland Halibut (Reinhardtius hippoglossoides Walbaum), from southern Labrador and South-eastern Gulf of. St. Lawrence. Northw. Atl. Fish. Sci., 1: 39-43.

Bradova N, Prodanov K. 2003. Growth rate of the whiting (Merlangius merlangus euxinus) from the western part of Black Sea. Bulgarian Academy of Sciences, 4: 157-164.

Çiloğlu E, Şahin C, Zengin M, Genç Y. 2001. Determination of Some Population Parameters and Reproduction Period of Whiting (Merlangius merlangus euxinus Nordmann, 1840) on the Trabzon-Yomra Coast in the Eastern Black Sea. Turk J Vet Anim Sci. 25 (2001) 831-837.

Dehnik TV. 1973. The Ichthyoplankton of the Black Sea, Kiev: Naukova dumka, In Russia, p. 234.

Göksungur E, Erdem Ü. 2005. Biology of the whiting (Merlangius merlangus euxinus, Nordmann 1840) in the Marmara Sea (Turkey), The 7th Balkan Conference on Operational Research, BACOR 05, Constanta, May 2005, Romania.

Hislop JRG, Hall WB. 1974. The fecundity of whiting, Merlangius merlangus (L.) in the North Sea, the Minch and at Iceland, J. Cons. int. Explor. Mer, 36(1): 42-49. Novembre.

Hislop JRG. 1975. The breeding and growth of whiting, Merlangius merlangus in captivity. J. Cons. Int. Explor. Mer, 36(2): 119-127.

Holden MJ, Raitt DFS. 1974. Manual of fisheries science. Part 2- Methods of resource investigation and their application. Rome: Food and Agriculture Organization of the United Nations. 
İşmen A. 1995. The Biology and Population Parameters of the Whiting (Merlangius merlangus euxinus Nordmann, 1840) in the Turkish Coast of the Black sea, Ph.D. Thesis, The Middle East Technical University Marine Biology and Fisheries, İçel, Turkey, p. 182.

Kandler R. 1958. Whiting, Baltic stock, German investigations. Annls biol. Copenh. 15: 123.

Maximov V, Nicolaev S, Radu G, Staicu, I. 2007. Estimation of growing parameters for main demersal fish species in the Romanian marine area. Recherches Marines, 38: 289-304.

Mazlum RE, Bilgin S. 2014. Age, growth, reproduction and diet of the whiting, Merlangius merlangus euxinus (Nordmann, 1840), in the southeastern Black Sea, Cah. Biol. Mar. (2014) 55: 463-474.

Mestorff J. 1959. Untersuchungen iiber die Biologie des Wittlings Merlangius meriangus (L.) in der Nordsee. Ber. Dt. Wiss. K.ommn f. Meeresforsch NF. 15, H. 4: 277-334.

Milić D, Kraljević M. 2011. Biometry analysis of the whiting, Merlangus merlangus (Linneaus, 1758) from the northern Adriatic Sea. Acta Adriat., 52(1): 125-136.

Murua H, Saborido-Rey F. 2003. Female reproductive strategies of marine fish species of the North Atlantic. J. Northwest Atl. Fish. Sci. 33: 23-31.

Murua H, Kraus G, Saborido-Rey F, Witthames PR, Thorsen A, Junquera J. 2003. Procedures to estimate fecundity of marine fish species in relation to their reproductive strategy. J. Northw. Atl. Fish. Sci. 33: 33-53.

Nedreaas K, Florin A, Cook R, Fernandes P, Lorance P. 2014. Merlangius merlangus. The IUCN Red List of Threatened Species 2014: e. T198585A45097610. http://dx.doi.org/ 10.2305/IUCN.UK.2014-3.RLTS.T198585A45097610.en. Downloaded on 23 October 2017.

Ricker WE. 1975. Computation and interpretation of biological statistics of fish populations. Bull. Fish. Res. Board Can. $191,382 \mathrm{p}$.
Sağlam N, Sağlam C. 2012. Population Parameters of Whiting (Merlangius merlangus euxinus L., 1758) in the SouthEastern Black Sea. Turkish Journal of Fisheries and Aquatic Sciences 12: 831-839

Samsun N, Erkoyuncu I. 1998. The research on the estimation of some parameters of whiting (Gadus merlangus euxinus Nordmann, 1840) caught by the bottom trawls in the area of Sinop (Black Sea) from the view point of fishery biology. Ege University Journal of Fisheries, 15: 19-31.

Şahin T, Akbulut B. 1997. Some population aspects of whiting (Merlangius merlangus euxinus Nordmann, 1840) in the eastern Black Sea coast of Turkey. Turkish Journal of Zoology, 21: 187-193.

Treasurer JW. 1981. Some aspects of the reproductive biology of perch Perca fluviatilis L. fecundity, maturation and spawning behavior. Fish Biology 18: 729- 740.

Tsai C, Gibson GR. 1971. Fecundity of the yellow perch, Perca flavescens Mitchill, in the Patuxent River, Maryland. Chesapeake Science 12: 270-284.

TUIK. 2016. Fishery statistics. Ankara, Turkish statistical institute.

Uysal A. 1990. Biology and Population Dynamics of Whiting (Merlangius merlangus euxinus Nordmann, 1840) in the Area of East Black Sea (Sinop-Hopa), (in Turkish). Doktora Tezi, T.C. İstanbul Üniv. Deniz Bilimleri ve Coğrafya Enstitüsü Deniz Biyolojisi Anabilim Dalı, İstanbul, Türkiye, $65 \mathrm{~s}$.

Valladolid M, Przybylski M. 2008. Life history traits of the endangered Iberian loach Cobitis calderoni in the River Lozoya, central Spain. Folia Zoologica 57 (1-2): 147-154.

Volodin SV. 1996. Morphological and Biological Particularities of Black Sea Whiting Merlangius merlangus euxinus (NORDMANN(T)e leostei: Gadidae), Marine Ecology, 17 (1-3): 549-559.

Whitehead PJP, Bauchot ML, Hureau JC, Nielsen J, Tortonese E. 1986. Fishes of the North-eastern Atlantic and the Mediterranean. Paris: UNESCO. 